Liquid rhizobial inoculants for lentil and field pea

${ }^{1}$ Russell K. Hynes, ${ }^{1}$ Douglas Covert, ${ }^{1}$ Robert J. Rennie and 2 R. Stewart Smith.

1 Imperial Oil, Chemicals Division, Ag Biologicals, 402-15 Innovation

Blvd.,Saskatoon,SK. S7N 2X8 Canada and 2LiphaTech Inc., 3101 W. Custer Ave.,Milwaukee, WI 53209 U.S.A.

\begin{abstract}
The traditional peat legume inoculants are viewed by western Canadian farmers as being difficult to apply. Accordingly, more "user-friendly" inoculants are being developed to ensure more wide-spread inoculation of legumes. A liquid inoculant developed by LiphaTech was evaluated as a carrier for Rhizobium

leguminosarum strains 99A1 for lentil and 128C56G for pea. These two strains survived at titres exceeding $\log 8.0$ per $\mathrm{mL}$ for ten months at $5^{\circ} \mathrm{C}$ and there was no loss of viability during shipping and handling. The Prairie Agricultural Machine Institute (PAMI) determined that the liquid inoculant gave a very flowable and uniform coverage of the seeds when applied through a grain auger and various types of seeding equipment. Liquid inoculant for pea and lentil resulted in yields equal or better than those observed for the traditional peat-based inoculant.
\end{abstract}

\title{
Introduction
}

Symbiotic N2 fixation occurs following the association of an effective strain of Rhizobium and its host plant. Depending on the legume, up to $60 \%$ of the plant's $\mathrm{N}$ requirement may be met by the conversion of atmospheric $N_{2}$ by the rhizobia to usable $N$ forms for the plant (Innovative Acres Report, 1987). Many western Canada soils do not contain sufficient numbers of Rhizobium to establish effective nodulation, leaving the plant dependent on deriving its $\mathrm{N}$ requirement from the soil. Inoculating seed with rhizobia insures that a large and effective population is available in the rhizosphere of the seedling allowing symbiosis to proceed immediately and meet the plants $\mathrm{N}$ requirement without interruption in its growth.

The success of establishing a $\mathrm{N}_{2}$-fixing legume crop is dependant on the carrier system used, the rhizobial strains and the inoculation practices. The carrier must support a large viable population of Rhizobium for several months in a suitable

physiological state to establish a symbiotic association with the host seedling. The carrier must be conducive to the rhizobia's ability to be effective in a variety of soil types, environmental conditions and it must be amenable to general agronomic practices (Paau, 1991).

Rhizobium has been applied to seed for several decades in a peat-based carrier. It has proven to be the most effective carrier as a result of the sustaining characteristics peat possess for microorganisms such as its high water holding capacity, high cation exchange (ie. buffering) capacity and abundant nutrient content (Nethery, 1989). In current farming practice seed is treated with one of several sticking agents (Elegba and Rennie, 
1984) followed by application of the peat to the seed while it is in the seed box or as it is moved by auger into seeding equipment. Peat-based inoculation practices in western Canada were recently reviewed and it was concluded that although peat was a very good carrier of Rhizobium, the inoculation procedures are generally time consuming, messy and impractical when sowing the large quantities of seed typically sown in this region (P.A.M.I., Food and Farm Report 91-01-03, 1991).

A liquid rhizobial soybean inoculant was developed by lipha Tech. We viewed this technology as a means of overcoming the difficulties of inoculating Rhizobium onto large quantities of seed. To accomplish this ESSO created new packaging for its lentil and pea inoculants. This study examines the shelf life and efficacy of two liquid inoculants Enfix-L, R. legumniosarum 99A 1 for lentils and Enfix-P, R. lequminosarum 128C56G for field pea.

Materials and Methods

\section{Inoculant system}

Packaging and a delivery system for the liquid inoculant was developed by ESSO. It was determined that the optimum system for western Canadian farmers would be one that could inoculate $1333 \mathrm{~kg}$ $(50 \mathrm{bu})$ of seed. To do this $4 \mathrm{I}$ of inoculant had to be maintained in a physiologically active state for a minimum of 3 months. Strains

Strains, R. leguminosarum 99AI and R. Ieguminosarum 128C56G, used in this study, have demonstrated superior $\mathrm{N}_{2}$ fixation and yield of lentil and field pea, respectively (Innovative Acres Reports, 1986, 1987 and 1988, Bremer et al., 1990).

Both strains were prepared in peat and liquid-based formulation at IiphaTech, Milwaukee, U.S.A. The strains in the liquid formulation were packaged into plastic bladders of $375 \mathrm{~mL}$ (packaging developed at LiphaTech) and 4 I sizes.

The viable counts of $\underline{R}$. leguminosarum in the liquid

formulation were determined periodically by removing a sample by syringe through a silicon septum on the bags, serially diluting the sample and spreading aliquots of the diluent onto yeast extract-mannitol agar. Colony forming units were counted after 3 days incubation at $25^{\circ} \mathrm{C}$. Field pea and lentil were inoculated with strains 128C56G (287 days old) and 99A1 (296 days old), respectively, and planted into a mixture of vermiculite and perlite. The pots were placed in a greenhouse and watered twice weekly with Hoaglands N-free nutrient solution. After 4 weeks, the plants were removed from the pots and the roots were inspected for nodule development.

Inoculation trials

Experiments to examine the feasibility of a liquid rhizobial inoculum for lentils and peas were carried out at the Prairie Agricultural Machinery Institute (P.A.M.I.), Humbolt, SK. Farm scale equipment such as a 100 bu bin to hold and release the seed and a auger ( $40 \mathrm{ft}$ by 7 in. operating at one-half speed) were used. The inoculum flowed through a hose $(1.5 \mathrm{~m}$ long) from the bladder 
to a tube inserted just above the boot of the auger and coated the lentil and field pea seed as it was carried up the auger to collect in the box of a grain truck. Seed was treated at the recommended rate suggested by the manufacture. Inoculated field pea and lentil seed was collected and planted (24 and 48 hours after inoculation) in pots containing vermiculite and perlite, and placed in the greenhouse. The plants were removed from the pots four weeks later and the tap root nodules were counted. Eield sites

Nine Saskatchewan farmers compared field pea inoculant (strain 128C56G) prepared in the liquid to that of the peat-based formulation. Seed was inoculated according to the manufactures recommendations (peat: $3.2 \mathrm{~kg} / 800 \mathrm{~kg}$ seed; liquid: $4 \mathrm{~L} / 1333 \mathrm{~kg}$ seed). The cultivars of pea included in this study were Victoria, Trapper, Radley, and Express. All procedures and equipment for inoculation and seeding were according to the farmers normal practices. Each farmer planted the two treatments on two 16 ha plots. Approximately 7 weeks after planting 10 plants from each treatment were removed and nodule development was evaluated. It was not possible to have a similar plot left uninoculated.

Research sites

Research experiments with lentils and field pea were planted in 1991 and 1992 for the purpose of comparing crop vigour, nodule development and grain yield following inoculation with the liquidand peat-based formulations. Nitrogen fixation was compared between treatments using the acetylene reduction technique (Hardy, Burns and Holsten, 1973). Field sites for lentil (cultivar Laird) and field peas (cultivar Express and Radley) were chosen with two criterion in mind; the site must be in an area where the crop has been traditionally grown and the soil $N$ level must be approximately $20 \mathrm{~kg} / \mathrm{ha}$. Field peas and lentils were mechanically planted into plots containing 5 treated rows 2.5 by $6 \mathrm{~m}$ using a custom built plot seeder (Fabro Ltd., Swift Current, SK.) and harvested using a Winterstieger plot combine. Experimental design was a randomized complete block with 8 and 4 replications in 1991 and 1992, respectively. The treatments included uninoculated seed, lentil and pea seed treated with $99 \mathrm{Al}$ or 128C56G, respectively, in the peat and liquid formulations. Statistical analysis was done using MSTAT-C. (Crops and Soil Sciences, Michigan State University, East Lansing, MI) by analysis of variance. Treatment mean separations were done by calculating the LSD at $\mathrm{p} \leq 0.05$ level of significance.

\section{Results}

A. Formulation/Packaging: Strain Survival

The population of $128 \mathrm{C} 56 \mathrm{G}$ and 99A1 exceeded $\log 8$ in the 375 $\mathrm{mL}$ (data not shown) and $4 \mathrm{I}$ plastic bladders after nine months (Fig. la and b). The shoots of field pea treated with inoculum from the plastic bags, $375 \mathrm{~mL}$ and $4 \mathrm{~L}$, were dark green and the crown region of the root and lateral roots were well nodulated.

B. P.A.M.I. Inoculation Trials 
Inoculation of lentil and field pea seed using the ESSO packaging and typical farm equipment demonstrated that our inoculation procedure was compatible with commonly used seeding equipment. Treated seed glistened with a moist coating and "coned up" as it collected in the truck box. Within 15 minutes the appearance of the seed returned to that prior to inoculating and showed no seed adhesion. In greenhouse experiments both crops were well nodulated and only a slight reduction in tap root nodule number was observed on plants from seed that was planted 48 hours after inoculation (Table 1 ). The lateral roots of the lentils and field pea were also nodulated.

Field experiments: A. Farm trials

All of the farmers indicated that the liquid formulation application time was reduced and was much easier to apply to seed than the peat-based formulation. All of the cultivars of field pea inoculated with the liquid and peat-based formulations were nodulated on the crown region of the root indicating that the nodulation commenced soon after germination of the crop (Table 2). Four of the farmers reported measured yields obtained from the two treatments (Fig.2) while the five remaining farmers visually estimated the yield of field peas. The results of these trials indicated that inoculation of field pea with the liquid-or the peat-based formulation gave similar yields (Fig. 2).

Field experiments: $B$. Research Trials

Lentil vigour, nodule rating and nitrogenase activity of lentil ( $\mathrm{C}_{2} \mathrm{H}_{2}$ reduction) were similar when inoculated with either of the formulations and they greatly exceeded those of the uninoculated treatment (Table 3). Inoculation with either the liquid or the peat-based formulation resulted in similar yield of lentils and regardless of the formulation used, these yields were significantly increased over the yield from uninoculated treatments at 7 of 9 field sites (Table 4).

Similar values for $\mathrm{N}_{2}$ fixation ( $\mathrm{C}_{2} \mathrm{H}_{2}$ reduction) and nodule rating with field peas inoculated with either formulation was observed (Table 5). The amount of nodulation of field pea observed in the untreated plots by the indigenous population of Rhizobium was greater than that of lentil, suggesting that field pea rhizobia are more promiscuous than lentil rhizobia. The lowest values for nodule rating and $\mathrm{N}_{2}$ fixation ( $\mathrm{C}_{2} \mathrm{H}_{2}$ reduction) were observed with the uninoculated treatments (Table 5). Similar yields of field pea were obtained with the liquid and peat-based formulation (Table 6).

\section{Discussion}

Establishing an effective $\mathrm{N}_{2}$-fixing symbiosis is highly dependant on a carrier delivering a large and efficacious population of Rhizobium to the host plant. For several decades farmers have relied on peat as a carrier of Rhizobium and while it is an effective delivery system it is messy and time consuming. Legume farming practice in western Canadian often involves 
inoculating sufficient seed for 500 acres (200 ha) or more. To seed this area in peas, 27 tons of seed will have to be inoculated, a task involving two or more people. Sticker is applied to the seed by one person while another adds peat to the moistened seed as it is moved by auger from the seed bin to a truck box or seed hopper. Therefore, it is not surprising that more "user-friendly" inoculants were requested by farmers (P.A.M.I., 1991).

Several factors contribute to a carriers successful maintenance of a large and effective population of Rhizobium. Peat is a component of soil, therefore, it possesses survival factors for microorganisms such as an diverse nutrient supply and high water holding capacity. The liquid formulation was also capable of maintaining a large and effective population of Rhizobium. The population of $\underline{R}$. leguminosarum strains $128 \mathrm{C} 56 \mathrm{G}$ and $99 \mathrm{~A} 1$ decreased by log 0.5 within 30 days of packaging in the plastic bladder and then was stable for the next 4 months. Crown and lateral root nodulation of field pea and lentil by inocula from either container was very good suggesting that this formulation maintains the rhizobia in a physiological state capable of establishing a symbiotic association with its host soon after germination. We cannot speculate on the mechanisms by which the rhizobia are surviving in the plastic bladder at this time, however, it is clear that our understanding of the survival of these organisms under these conditions is lacking.

The liquid formulation was amenable with commonly used farm equipment. The pea farmers reported that application of the liquid inoculant was easy and less time consuming than the peat-based inoculant. In addition, strain $128 \mathrm{C} 56 \mathrm{G}$ nodulated four cultivars of pea equally well.

The lentil trials were planted at sites where the farmers have included lentils in their crop rotation. Inoculation with $\underline{R}$. lequminosarum $99 \mathrm{Al}$ was required at seven of the nine sites for effective nodule development and $\mathrm{N}_{2}$ fixation. These results indicate that the population of Rhizobium that nodulate lentils do not survive at levels required for effective nodulation in western Canadian soils.

Peas present a greater challenge. The majority of pea production in western Canada occurs in the black soil zone where the $\mathrm{N}$ transformation rates are generally high ( $\mathrm{R}$. Karamanos, personal communication) and therefore the benefits of inoculation are not always observed. In addition, there was an effective indigenous population of Rhizobium at some of the field sites. indicating that these soils may maintain an effective Rhizobium population. However, as the results indicate this is not always consistent

Over one million acres of peas and lentils are planted in western Canada. Farmers recognize the benefit of growing legumes in rotation with other crops but many have excluded legumes because of the difficulties of inoculation. The ease of application of a liquid inoculant may promote more farmers to include legumes in their planting schedule. 
Acknowledgements

The authors thank Alan Boyden (PAMI), Kent Craig, Michelle

Schelke, Leighton Funk and Michelle Nutting for their excellent technical assistance.

\section{References}

Bremer, E., C.van Kessel, I. Nelson, R.J. Rennie and D.A. Rennie. 1990. Selection of Rhizobium leguminosarum strains for lentil (Lens culinaris) under growth room and field conditions. Plant and Soil 121, 47-56.

Elegba and Rennie, 1984. Effect of different inoculant adhesive agents on nodulation, rhizobial survival, nitrogenase activity and yield of soybeans. Can. J. Soil Sci. 64, 631-636.

Hardy, R.W.F., R.C. Burns, and R.D. Holsten. 1973. Application of the acetylene-ethylene assay for measurement of nitrogen fixation. Soil Biol. Biochem. 5, 47-81.

Nethery, A.A. Inoculant production with nonstertile carrier. In "Report on the expert consultation on legume inoculant production and quality control", Food and Agriculture Organization of the United Nations, Rome, 1991.

Paau, A. S. 1991. Improvement of Rhizobium inoculants by mutation, genetic engineering and formulation. Aiotech. Adv. 9, 173-184. 


\section{R. Leguminosarum 99A1}
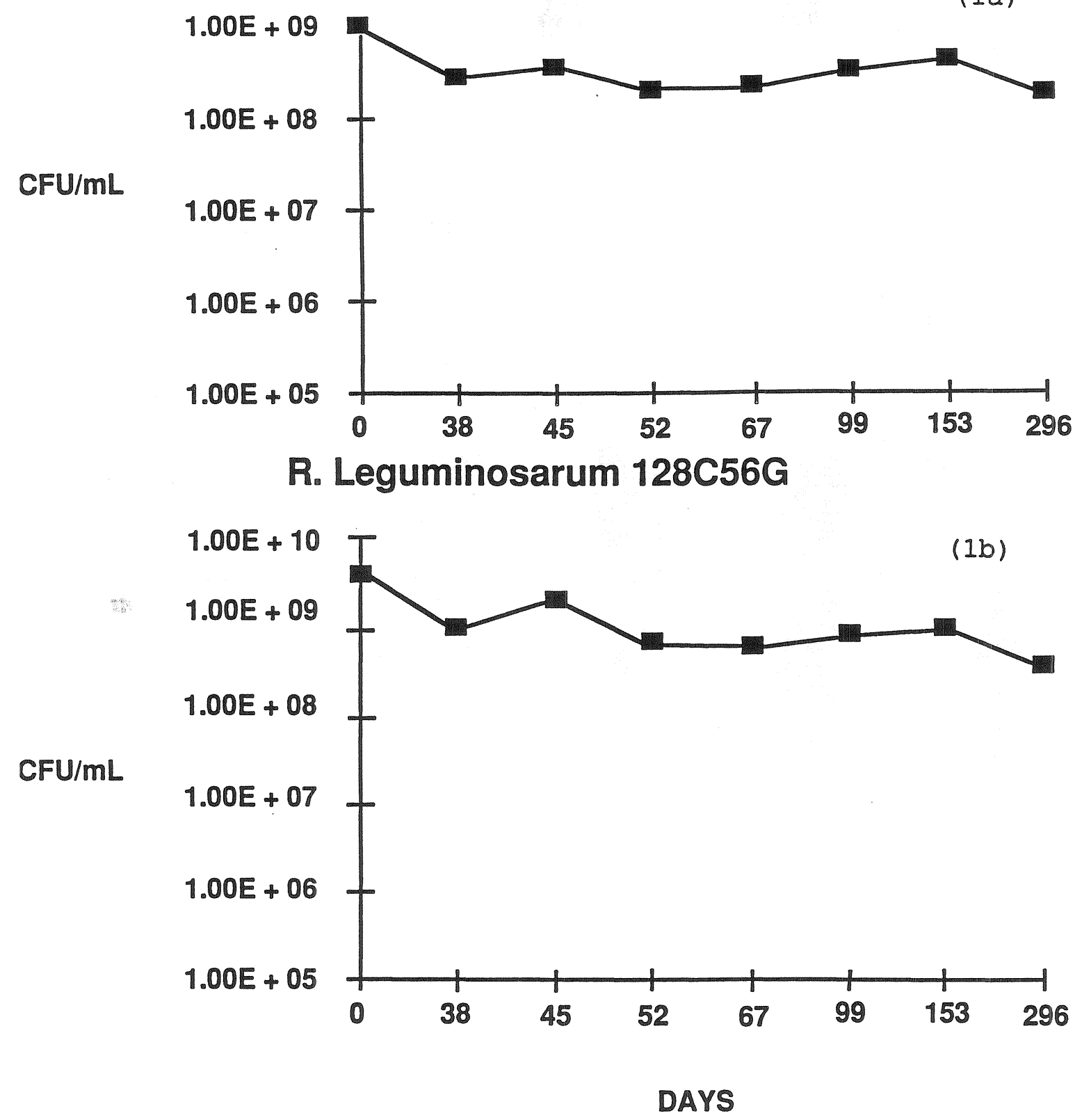

Figure 1.Survival of B. Leguminosarum $99 \mathrm{Al}$ (1a) and $128 \mathrm{C} 56 \mathrm{G}$ (1b) in a $4 \mathrm{~L}$ of liquid formulation. 
Enfix-P Liquid vs Enfix-P Poat Saskatchowan Famer Conducted Trials 1991

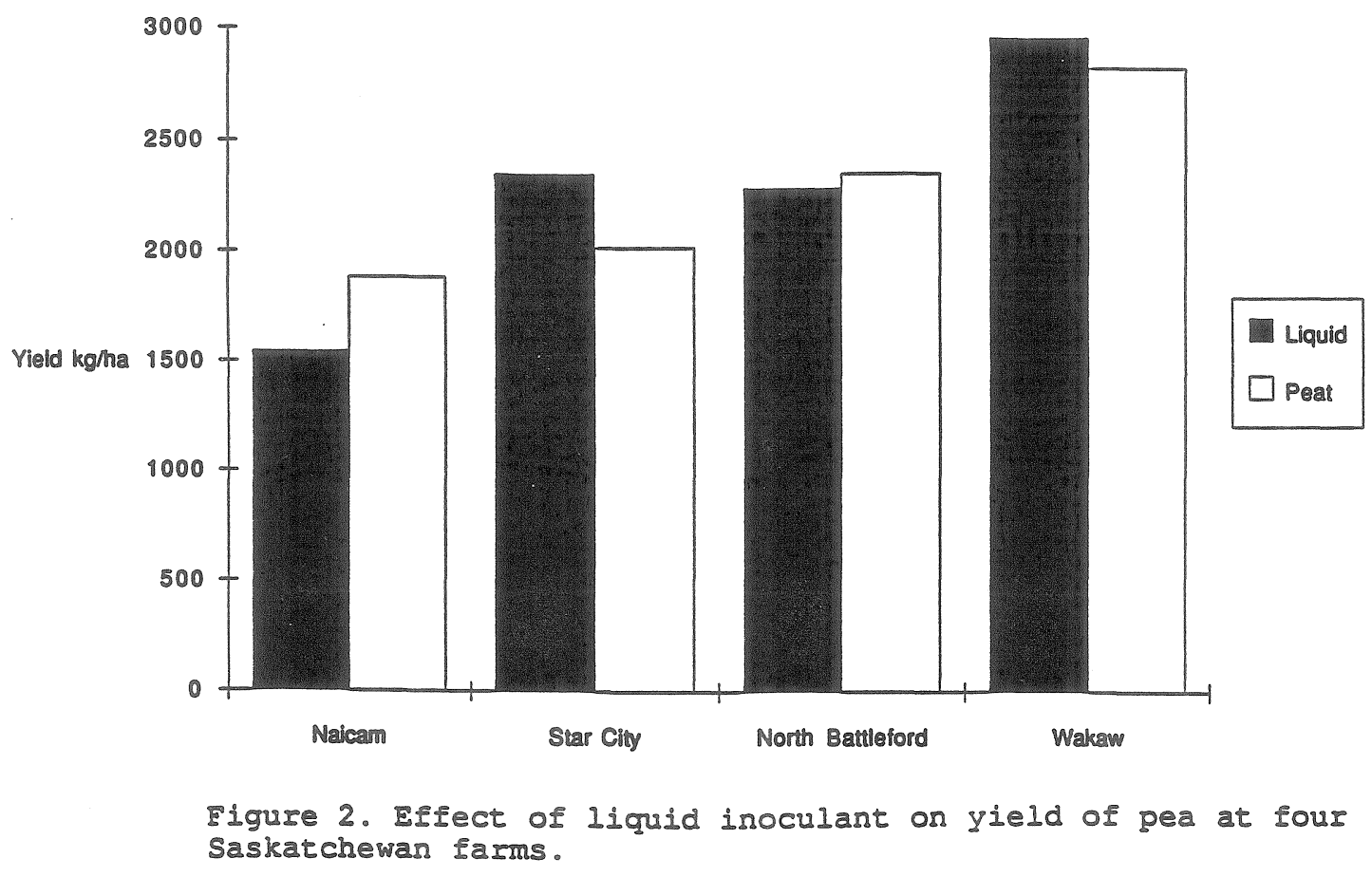

Table 1 Nodule counts on tap roots of field pea and lentil inoculated with liquid phizobial carrier.

\begin{tabular}{|c|c|c|c|}
\hline \multirow[t]{2}{*}{ Crop } & \multirow{2}{*}{\multicolumn{2}{|c|}{$\begin{array}{c}\text { Number of nodules/tap root }{ }^{1} \\
24 \mathrm{~h}\end{array}$}} & \multirow[b]{2}{*}{$48 h^{2}$} \\
\hline & & & \\
\hline Field pea & $12.7 \pm 1.0(11)^{3}$ & $15.6 \pm 0.7(14)$ & $11.2 \pm 0.9(15)$ \\
\hline Lentil & $15.2 \pm 0.5(13)$ & $15.8 \pm 0.8(13)$ & $11.1 \pm 0.1(15)$ \\
\hline
\end{tabular}


Table 2 Nodulation of various cultivars of field pea by B. Lequminosarum 128C56G.

Effect of formulation on crown nodulation and nodule rating.

\begin{tabular}{|c|c|c|c|c|c|}
\hline bocation & Cultivar & $\begin{array}{c}\text { Previous } \\
\text { Crop }\end{array}$ & Treatment & $\begin{array}{l}\text { \%Crown } \\
\text { Nodulation }\end{array}$ & $\begin{array}{l}\text { Nodule } \\
\text { Rating }\end{array}$ \\
\hline Radisson & Victoria & Fallow & $\begin{array}{l}\text { Peat } \\
\text { Liquid }\end{array}$ & $\begin{array}{l}100 \\
100\end{array}$ & $\begin{array}{l}5 \\
5\end{array}$ \\
\hline Payton & Trapper & Wheat & $\begin{array}{l}\text { Peat } \\
\text { Liquid }\end{array}$ & $\begin{array}{l}80 \\
60\end{array}$ & $\begin{array}{l}3 \\
2\end{array}$ \\
\hline Nipawin & Trapper & Wheat & Peat & $\begin{array}{l}90 \\
80\end{array}$ & $\begin{array}{l}4 \\
4\end{array}$ \\
\hline Star City & Radley & Flax & Peat & $\begin{array}{l}100 \\
80\end{array}$ & 4.5 \\
\hline Tisdale & Trapper & Canola & $\begin{array}{l}\text { Peat } \\
\text { Liquid }\end{array}$ & $\begin{array}{l}100 \\
100\end{array}$ & $\begin{array}{l}5 \\
5\end{array}$ \\
\hline N.Battleford & Victoria & Wheat & $\begin{array}{l}\text { Peat } \\
\text { Liquid }\end{array}$ & $\begin{array}{l}100 \\
100\end{array}$ & $\begin{array}{l}3 \\
3\end{array}$ \\
\hline Wakaw & Express & Canola & $\begin{array}{l}\text { Peat } \\
\text { Liquid }\end{array}$ & $\begin{array}{l}100 \\
100\end{array}$ & $\begin{array}{l}5 \\
5\end{array}$ \\
\hline Naicam & Trapper & Flax & $\begin{array}{l}\text { Peat } \\
\text { Liquid }\end{array}$ & $\begin{array}{l}100 \\
100\end{array}$ & $\begin{array}{l}2.5 \\
2.5\end{array}$ \\
\hline Melfort & Radley & Barley & $\begin{array}{l}\text { Peat } \\
\text { Liquid }\end{array}$ & $\begin{array}{l}100 \\
100\end{array}$ & $\begin{array}{l}3.5 \\
3.5\end{array}$ \\
\hline
\end{tabular}

Ten plants per treatment examined.

1. Per cent crown root nodulation calculated from the total number of plants examined per treatment.

2. Nodule rating: 0 -no nodules to 5-excellent nodulation.

Table 3 Effect of inoculation with Bhizobium lequminosarum 99A1 in peat of liquid formulation on vigour and nodule rating and \% crown nodulation of lentil (CV. Laird) in the field.

Treatment

\begin{tabular}{lccc}
\hline Treatment & Vigour Rating & Nodule Rating & $\mu$ mol $22 \mathrm{H} 4 / \mathrm{g} \mathrm{dry}$ root $^{2}$ \\
\hline Peat & 3.5 & 3.1 & $6.10 \pm 1.17$ \\
Liquid & 3.3 & 3.0 & $7.22 \pm 0.65$ \\
Uninoculated & 1.9 & 1.2 & $0.41 \pm 0.37$ \\
\hline
\end{tabular}

1.Vigour and nodule rating use a scale of 0 (no growth or nodulation) to 5 (excellent growth and nodulation). Vigour rating represents mean of 3 sites (Kindersely, Raymore and Rosetown 2). Nodule rating represents the mean of 5 sites (Kindersely, Soverign, Raymore, Success and Moose Jaw).

2 Acetylene reduction data from 1992 field site only.

Table 4. Inoculation of R. leguminosarum 99A1 on lentil. Effoct of formulation on grain yield in 1991 and 1992 field experiments.

\begin{tabular}{lccccccccccc}
\hline \multicolumn{10}{c}{ Yield $(\mathrm{kg} / \mathrm{ha})$} \\
\hline Treatments & Raymore & Rosetown Moosejaw & Success & Sovereign & Success & Outlook & Raymore Rosetown \\
\hline 99A1 Liquid & 1270 & 2174 & 2691 & 2717 & 3118 & 1014 & 1241 & 1931 & 2195 \\
99A1 Peat & 1219 & 1916 & 2381 & 2573 & 3275 & 1318 & 1123 & 2151 & 2369 \\
Uninoculated & 876 & 1370 & 2230 & 2038 & 3122 & 656 & 1275 & 950 & 1022 \\
LSD & 339 & 257 & 433 & 356 & 382 & 413 & 457 & 747 & 506 \\
\hline
\end{tabular}

Table 5 Effect of inoculation with R. leguminosarum $128 \mathrm{C56G}$ in peat and liquid formulation on nodule rating and nitrogen fixation $\left(\mathrm{C}_{2} \mathrm{H}_{2}\right.$ reduction) on pea (cv Radloy and Express)

\begin{tabular}{|c|c|c|c|}
\hline Treatment & & & $\mu \mathrm{mol} \mathrm{C}_{2} \mathrm{H}_{4} / \mathrm{g}$ dry weigth root2 \\
\hline & 1991 & 1992 & \\
\hline $\begin{array}{l}\text { Peat } \\
\text { Liquid } \\
\text { Uninoculated }\end{array}$ & $\begin{array}{l}3.5 \\
2.6 \\
1.3\end{array}$ & $\begin{array}{l}3.8 \\
3.6 \\
2.5\end{array}$ & $\begin{array}{l}8.46 \pm 3.54 \\
8.43 \pm 1.11 \\
5.89 \pm 1.39\end{array}$ \\
\hline
\end{tabular}

1: Mean nodule rating for 1991 obtained from experiments at Redwated, North

Battleford, and Brandon. Mean nodule rating for 1992 obtained from experiments at

Redwater, Pigeon Lake and Saskatoon.

2: Acetylene reduction from the 1992 experiments

Table 6. Inoculation of R. leguminosarum 128C56G on field pea.

Effect of formulation on grain yield in 1991 and 1992 field experiments.

\begin{tabular}{|c|c|c|c|c|}
\hline \multirow{2}{*}{\multicolumn{2}{|c|}{ Redwater }} & \multicolumn{3}{|c|}{ Yield (kg/ha) } \\
\hline & & Pigeon Lake & Saskatoon & Redwater \\
\hline Treatments & 1991 & & 1992 & \\
\hline 128C56G Liquid & 4376 & 2194 & 3361 & 4143 \\
\hline 128C56G Peat & 4339 & 3058 & 3009 & 3856 \\
\hline Uninoculated & 4200 & 2680 & 2804 & 3370 \\
\hline LSD & 524 & 938 & 776 & 637 \\
\hline
\end{tabular}

